Session 3160

\title{
Ohio University's Global Learning Community
}

\author{
Brian Manhire, Gregory A. Emery, David H. Mould, Carey M. Noland \\ Ohio University
}

\begin{abstract}
An overview of Ohio University's Global Learning Community (GLC) is presented from the perspective of contemporary engineering education. The GLC's multidisciplinary approach to studying international themes in a global context through its pedagogy of project- and team-based learning is described in relation to recent changes in ABET requirements (EC2000) for accrediting undergraduate engineering education programs. Programmatic challenges presently inhibiting extensive collaboration between the GLC and engineering education at Ohio University are described as well as opportunities for marginally improving collaboration despite these challenges.
\end{abstract}

\section{Introduction}

A university-wide committee of faculty and administrators designed Ohio University's Global Learning Community in 1996-97. It began operating as an experimental program in fall 1998 and was officially inaugurated as a formal university certificate-granting program on November 23, 1999. ${ }^{1}$

The GLC's raison d'être is to provide opportunities to internationalise curricula across campus. It offers a thirty-credit, two-year undergraduate residential certificate. ${ }^{2}$ Admission is competitive and open to all majors; and the certificate is intended to complement all undergraduate degree programs at the university. Its program of study is based on projects having international themes, which are in some cases undertaken in co-operation with real-world clientele.

Students enter the program at the beginning of either their sophomore or junior year, with many living and learning together in Bromley (residence) Hall—which is also where the GLC's classroom, computer laboratory and administrative office is located. The communal component also includes extracurricular student-faculty activities such as dining together and arranging and attending cultural events together. Certificate requirements include two required international experiences abroad. International perspective, project- and team-based learning, community and international experiences (abroad) constitute the synergism that is the essence of the Global Learning Community.

The faculty is competitively selected from across campus to deliberately form a multidisciplinary teaching team. Typically, there are three core faculty serving the GLC by way of half-time temporary appointments who return to their full-time permanent (home) faculty appointments after two or three years. In 
this way, since its inception, the GLC has drawn its faculty from the university's colleges of arts and sciences, business, communication and engineering. A permanent director, who is also a faculty-team member, leads the GLC.

While international themes comprise the foundation for the intellectual content of the GLC's entire program of study, academic and vocational processes are also important. These include developing student proficiencies such as: the ability to work in multidisciplinary teams (interpersonal skills), the ability to identify and conduct appropriate research as well as the ability to communicate effectively through both writing and public speaking. Through real-world projects of contemporary interest having international themes, the GLC strives to foster these proficiencies in a global and societal context while imparting knowledge and developing professional skills applicable to life-long learning.

The intellectual and professional development of GLC students includes exposure to professional and ethical responsibility and is achieved primarily (but not exclusively) by way of the GLC's reliance on project- and team-based learning concepts from problem-based-learning pedagogy (PBL). ${ }^{3}$ The GLC's implementation of project- and team-based learning includes extensive use of the Internet both as a research tool and as the primary communication medium outside the classroom (by way of the GLC on-line (Internet) database and electronic mail). ${ }^{4}$ GLC students also routinely use presentationgraphics software, e.g.; PowerPoint ${ }^{\mathrm{TM}}$, as well as word-processing and spreadsheet software.

The GLC's focus on developing academic and vocational skills (processes) through multidisciplinary team- and project-based study of international themes (content) is intended to enhance all traditional curricula —including those in the engineering disciplines. Nationally, engineering curricula are now changing considerably in response to recently mandated changes in accreditation requirements. In the United States, reputable undergraduate engineering education programs are accredited by the Accrediting Board for Engineering and Technology (ABET) ${ }^{5-6}$ and ABET's current accreditation paradigm is Engineering Criteria 2000 (EC2000). ${ }^{7-8}$ EC2000's third criterion is:

\section{Criterion 3. Program Outcomes and Assessment}

Engineering programs must demonstrate that their graduates have:

(a) an ability to apply knowledge of mathematics, science, and engineering

(b) an ability to design and conduct experiments, as well as to analyze and interpret data

(c) an ability to design a system, component, or process to meet desired needs

(d) an ability to function on multi-disciplinary teams

(e) an ability to identify, formulate, and solve engineering problems

(f) an understanding of professional and ethical responsibility

(g) an ability to communicate effectively

(h) the broad education necessary to understand the impact of engineering solutions in a global and societal context

(i) a recognition of the need for, and an ability to engage in life-long learning

(j) a knowledge of contemporary issues

(k) an ability to use the techniques, skills, and modern engineering tools necessary for engineering practice. 
Each program must have an assessment process with documented results. Evidence must be given that the results are applied to the further development and improvement of the program. The assessment process must demonstrate that the outcomes important to the mission of the institution and the objectives of the program, including those listed above, are being measured. Evidence that may be used includes, but is not limited to the following: student portfolios, including design projects; nationally-normed [sic] subject content examinations; alumni surveys that document professional accomplishments and career development activities; employer surveys; and placement data of graduates. ${ }^{9}$

It is self-evident that elements of this criterion coincide with the GLC's mission and pedagogy, and, as a result, some collaboration between the GLC and the Ohio University's Russ College of Engineering and Technology has begun. However, as will be describe later in this article, this collaboration has been somewhat inhibited.

\section{GLC Statistics, Curriculum and Pedagogy}

GLC enrolments are tabulated in table 1 where breakdowns are provided by both year and by home colleges, i.e.; the GLC certificate program is adjunct to the degree programs offered by the university's various colleges. These figures encompass all students enrolled in GLC courses; and except as noted (i.e., engineering students) all enrolment figures are for students pursuing the GLC certificate.

\begin{tabular}{|c|c|c|c|c|c|}
\hline \multirow[b]{2}{*}{ College } & \multicolumn{4}{|c|}{ Academic Year- } & \multirow[b]{2}{*}{ Totals } \\
\hline & 1998-1999 & 1999-2000 & $2000-2001$ & 2001-2002 & \\
\hline Arts \& Sciences & 0 & 2 & 4 & 26 & 32 \\
\hline Business & 12 & 17 & 12 & 12 & 53 \\
\hline Communication & 25 & 29 & 18 & 21 & 93 \\
\hline Education & 0 & 0 & 0 & 1 & 1 \\
\hline Engineering & 0 & 0 & $3^{*}$ & 0 & $3^{*}$ \\
\hline Fine Arts & 0 & 0 & 0 & 1 & 1 \\
\hline Health \& Human Services & 0 & 0 & 1 & 3 & 4 \\
\hline Honors Tutorial & 1 & 1 & 1 & 1 & 4 \\
\hline University College & 1 & 0 & 2 & 13 & 16 \\
\hline Totals: & 39 & 49 & 41 & 78 & 207 \\
\hline
\end{tabular}

* Indicates non-certificate enrolments

Table 1. GLC enrolments, all courses

Certificate requirements include the eight GLC project-courses shown in table 2, two international experiences abroad and proficiency in a foreign language through the sophomore level. GLC 202 fulfills the first international experience requirement by way of on-line (database) project collaboration with students at a foreign university culminating in two-weeks of project work overseas (table 3). The second is satisfied either through a formal GLC internship abroad (or an internationally oriented domestic 
internship) or by completing one of the more traditional study abroad programs available at Ohio University. GLC students are advised to complete auxiliary coursework in (cultural) anthropology, microand macroeconomics, geography, (nonwestern) history, political science and sociology. ${ }^{10}$

\begin{tabular}{|c|c|c|}
\hline \multicolumn{3}{|r|}{ First Year } \\
\hline Term (Quarter) & Course ID (Credits) & Course Title \\
\hline \multirow[t]{2}{*}{$\overline{\text { Fall }}$} & GLC $201(3)$ & Global Learning Community Introductory Project \\
\hline & GLC $202(5)$ & Business and Communication in Transitional Societies \\
\hline \multirow[t]{2}{*}{ Winter } & GLC 203 (4) & Building Cross-National Alliances \\
\hline & GLC 204 (4) & Communication and Development \\
\hline \multirow[t]{2}{*}{ Spring } & GLC 205 (2) & Global Leadership Conference \\
\hline & & Second Year \\
\hline Fall & GLC 301 (4) & Global Economic Trends and Strategic Alliances \\
\hline Winter & GLC 302 (4) & Global Competition and Industry Trends \\
\hline \multirow[t]{2}{*}{ Spring } & GLC $303(4)$ & Starting a New Venture/Initiative \\
\hline & & Continuously Scheduled Courses \\
\hline All & GLC $400(0-6)$ & International Internship \\
\hline All but Summer & GLC $169(1)$ & The Global Experience \\
\hline
\end{tabular}

Table 2. GLC courses and program of study

\begin{tabular}{|c|c|c|c|}
\hline Year & Country & $\begin{array}{l}\text { Collaborating Overseas } \\
\text { Educational Institution }\end{array}$ & Clientele \\
\hline 1998 & Hungary & Janus Pannonius University & $\begin{array}{l}\text { Electric power station, computer manufacturer, } \\
\text { television station, economic development agency, } \\
\text { clothing manufacturer, tourism agency and a hotel }\end{array}$ \\
\hline 1999 & Ecuador & $\begin{array}{l}\text { Centro de Estudios } \\
\text { Interamericanos }\end{array}$ & $\begin{array}{l}\text { Leather goods manufacturer, automobile importer, } \\
\text { candy factory, hospital and a women's handicrafts } \\
\text { cooperative }\end{array}$ \\
\hline 2000 & $\begin{array}{l}\text { Czech } \\
\text { Republic }\end{array}$ & Masaryk University & $\begin{array}{l}\text { Telecommunications company, truck body manu- } \\
\text { facturer, domestic gas-boiler manufacturer, Envi- } \\
\text { ronmental Partnership for Central Europe, Brno } \\
\text { Airport Authority, Brno City Architect's Office and } \\
\text { the National Theater of Brno }\end{array}$ \\
\hline 2001 & Thailand & Bangkok University & $\begin{array}{l}\text { Mass Rapid Transit Authority of Thailand, client- } \\
\text { server computing systems' supplier, frozen-food } \\
\text { and beverage manufacturers, amusement park, ho- } \\
\text { tel, clothing manufacturer, automobile dealership } \\
\text { and a coffee shop chain }\end{array}$ \\
\hline
\end{tabular}

Table 3. GLC 202 overseas joint consulting projects 
Team-based course projects, some undertaken in conjunction with real clients, are the backbone medium of instruction in most GLC courses. For example, one project entailed developing new-product proposals for improving the quality of life in Latin America for The Procter \& Gamble Company. Another was to develop a strategy to increase sales of processed steam at the Pécs Power Station in Hungary. Yet another was to develop a strategic plan to raise public awareness of environmental issues and funding for environmental projects in the Czech Republic for the Environmental Partnership for Central Europe.

Students learn in teams by completing a variety of project tasks. Although faculty may prescribe some pro forma tasks such as performing SWOT (strengths, weaknesses, opportunities and threats), country, region, market and industry analyses with concomitant presentations and project documentation, other pertinent tasks may be performed ad hoc as course projects unfold.

Some GLC projects are deliberately undertaken cooperatively with foreign universities so that GLC student-teams have the opportunity to collaborate with peer-groups overseas (table 3 ). In the Fall 2001 offering of GLC 301, second-year GLC students collaborated with their counterparts at the American University in Kyrgyzstan in a joint venture funded by the Council for the International Exchange of Scholars. ${ }^{11}$ This collaboration was carried out by way of the GLC's on-line Internet database and included twelve students from a dual senior- and graduate-level Ohio University political science course entitled Nonprofit Management. (GLC 301's clientele consisted of five NGOs in Kyrgyzstan.)

Independent of its certificate program, the GLC has recently introduced a new, one-credit stand-alone freshman (pass/fail) course GLC 169: The Global Experience. The aim of this course is to provide a campus-wide opportunity for beginning students (freshmen) to both learn about the GLC and explore foreign cultures in a pleasant setting without enduring rigorous demanding course requirements (the course has no prerequisite course requirements and no letter-grades are awarded). Active learning is facilitated mostly through edifying, pleasant and entertaining class activities such as cooking exercises (i.e., students prepare foreign cuisine and then eat what they have wrought!), music and dance performances and instruction as well as through guest speakers. Students also undertake mini-projects based on international themes. The university draws upon its considerable pool of talent (e.g., foreign-student organizations, faculty with experience abroad, etc.) for facilitators of these class activities.

\section{The GLC and Engineering Education at Ohio University}

Ohio University (http://www.ohiou.edu/) is a public university located in Athens, Ohio that provides a broad range of educational programs and services. There are 28,115 students (total) and 901 full-time faculty (Athens main campus) at the university. ${ }^{12}$ The Fritz J. and Dolores H. Russ ${ }^{13}$ College of Engineering and Technology (RCENT) is the locus of engineering education at the university and is located in the C. Paul and Beth K. Stocker ${ }^{14}$ Engineering and Technology Center. The college is organized into departments of aviation, industrial technology; civil, chemical, mechanical and industrial and 
manufacturing systems engineering; and the school of electrical engineering and computer science. It awards B.S., M.S. and Ph.D. degrees. College statistics include an undergraduate enrolment of 884 students and 72 faculty with 83 and 14 masters and doctoral degrees awarded respectively. ${ }^{15}$

All undergraduate engineering curricula are presently ABET accredited under pre-EC2000 criteria and are thus now undergoing continuous improvement ${ }^{16}$ in order to meet EC2000 requirements. It would appear that, given its mission and modus operandi, there are opportunities for the GLC to assist engineering education at Ohio University in this endeavor. However, opportunities for such collaboration are limited because of the curricular demands of both RCENT and the GLC. For example, there is very little curricular overlap between the requirements for RCENT's undergraduate degrees and the GLC's certificate. This impediment is exacerbated by a lack of free-elective course opportunities endemic to engineering education at Ohio University as well as across the United States. ${ }^{17}$ The GLC's certificate program is not immune to this sort of curricular inflexibility either (table 2). So given the present situation, it is unlikely that many engineering students will pursue the GLC's certificate during the course of earning their degrees since that would delay their graduation considerably.

Despite these curricular incompatibilities, there are other avenues for growing RCENT-GLC collaboration. The chemical engineering department has allowed their students to enroll in GLC 302 for (technical-elective) degree credit. Preliminary discussions are underway to expand this to other engineering disciplines. In addition, it may also be possible in the future for the GLC to offer service courses that enable RCENT students to satisfy some of EC2000 Criterion 3 in situ. By in situ, we mean engineering students working within GLC-course multidisciplinary teams on projects germane to contemporary issues in a global context. These cooperative technical-elective and service-course schemes may serve as a conduit allowing the GLC to assist RCENT in meeting some of its nascent accreditation needs while fulfilling the GLC's raison d'être — to provide opportunities to internationalise curricula across campus.

\section{Recapitulation and Conclusion}

Ohio University's Global Learning Community strives to provide opportunities to internationalise curricula across campus through project- and (interdisciplinary) team-based learning organized around international themes. This approach is compatible with some of the recent changes in engineering education accreditation requirements confronting engineering education programs across the country - especially in areas that, before the advent of EC2000, were not emphasised in traditional engineering curricula. These changes are motivated, in part, by the global dimensions (globalization ${ }^{18-19}$ ) of contemporary professional workforce needs. ${ }^{6,20-21}$

Potential means to overcome impedimenta to further collaboration between the GLC and the Russ College have been described. These include the use of some upper-level GLC coursework as senior technical electives in more engineering curricula and perhaps making enrolment in some lower-level GLC courses required in some engineering curricula — in order to meet some of the nascent accreditation needs of the Russ College. 
The GLC is not a traditional degree-granting academic discipline but rather a means to enhance the curricula of such disciplines. Although its forte is its certificate program, as described herein, it is nonetheless important for the GLC to explore other means of fulfilling its mission; and it is with this intent that this article has been written.

References

1. David H. Mould et al., "Global Learning Community Certificate Proposal," (unpublished) proposal to the Ohio University Curriculum Council Programs Committee, November 23, 1999.

2. Alice J. Irby, "Postbaccalaureate [sic] Certificates: Higher Education's Growth Market," Change, March/April 1999, 36-41.

3. Barbara J. Duch, Susan E. Groh and Deborah E. Allen eds., The Power of Problem-Based Learning: A Practical "How To" for Teaching Undergraduate Courses in Any Discipline, (Sterling, Virginia: Stylus Publishing, LLC, 2001), passim.

4. John Seely Brown, "Growing Up Digital: How the Web Changes Work, Education, and the Ways People Learn," Change, March/April 2000, 10-20.

5. Richard G. Denning, "Professional Accreditation of Engineering, Engineering Technology, and EngineeringRelated Programs in the United States: 1932-2000+," Proceedings of the ASEE/SEFI/TUB International Colloquium: Global Changes in Engineering Education, Berlin, Germany, September 15-18, 2001, np. URL: http://www.asee.org/conferences/international/proceedings/default.cfm

6. William R. Dill, "Specialized Accreditation: An Idea Whose Time Has Come? Or Gone?," Change, July/August 1998, 18-25.

7. Trudy E. Bell, "Proven skills: the new yardstick for schools," IEEE Spectrum, Vol. 37, No. 9, September 2000, 6367. URL: http://www.spectrum.ieee.org/publicfeature/sep00/abet.html, also see URL: http://www.abet.org/

8. Jane V. Wellman, "Accreditors Have to See Past 'Learning Outcomes'," The Chronicle of Higher Education, 22 September 2000, B20. URL: http://chronicle.com/weekly/v47/i04/04b02001.htm

9. Criteria for Accrediting Engineering Programs: Effective for Evaluations During the 2001-2002 Accreditation Cycle (Baltimore, Maryland: Accreditation Board for Engineering and Technology, 2000), 1-2. URL: http://www.abet.org/images/eac criteria b.pdf

10. Ohio University Undergraduate Catalog 2001-2002 (Athens, Ohio: Ohio University Office of University Publications, 2001), 38-39, 94, 302-303.

11. David H. Mould, "American University in Kyrgyzstan - Global Learning Community Collaborative Student Research and Consulting Project: Final Grant Report to the Council for International Exchange of Scholars," Grant Number: AIAM75295, March 2002.

12. Ohio University Fact Card, Ohio University Publications (6046-5M), 2001.

13. David Neal Keller, The Russ Influence: A Biography of Fritz \& Dolores Russ (Athens, Ohio: Ohio University Russ College of Engineering and Technology, 1996), Ohio University Printing Resources 35346-1.5.

14. David Neal Keller, C. Paul Stocker: His Life and Legacy (Athens, Ohio: Ohio University Press, 1991).

15. ASEE Directory of Engineering Colleges - Profiles (Washington, D.C.: American Society for Engineering Education, 2000). URL: http://www.asee.org/publications/colleges/

16. Robert Birnbaum, Management Fads in Higher Education: Where They Come From, What They Do, Why They Fail (San Francisco, California: Jossey-Bass, 2000), 91-108.

17. Phillip Wankat and Frank Oreovicz, "TEACHING TOOLBOX: Teaching - An Overstuffed Curriculum," ASEE Prism, Vol. 11, No. 2, October 2001, 40. URL: http://www.asee.org/prism/oct01/teaching.cfm?

18. Thomas L. Friedman, The Lexus and the Olive Tree (New York, New York: Random House, Inc., Anchor Books, 1999, 2000), pas sim.

19. Fareed Zakaria, "Special Report: Why Do They Hate Us?," Newsweek, 15 October 2001, 22-40.

20. John R. Schermerhorn, James G. Hunt and Richard N. Osborn, "Global Dimensions of Organizational Behavior," in Organizational Behavior, $7^{\text {th }}$ ed., (New York, New York: John Wiley \& Sons, Inc., 2000), 39-58.

21. Catherine S. McGowan, “Assignment: Overseas,” Today's Engineer, Vol. 3, No. 2, $2^{\text {nd }}$ Quarter 2000, 12-16. URL: http://38.204.37.84/magazine/vol3num2/v3n2features/pg.12.htm 
BRIAN MANHIRE

Brian Manhire (manhire@ ohio.edu, http://www.ent.ohiou.edu/ manhire/) is a professor of electrical engineering at Ohio University.

GREGORY A. EMERY

Gregory A. Emery (emery@ ohio.edu, http://www.ohiou.edu/glc/) is the Director of the Global Learning Community and a lecturer of finance and marketing at Ohio University.

DAVID H. MOULD

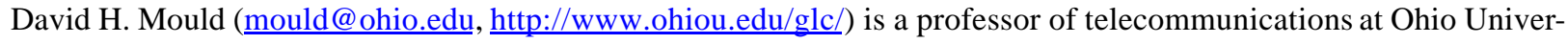
sity.

CAREY M. NOLAND

Carey M. Noland (noland@ ohio.edu, http://www.ohiou.edu/glc/) is an assistant professor of interpersonal communication at Ohio University. 